\title{
UPAYA PENINGKATAN HASIL BELAJAR PESERTA DIDIK PADA MATERI STATISTIKA MELALUI MODEL PEMBELAJARAN KOOPERATIF TIPE JIGSAW
}

\author{
Syamsudin \\ SMA N 1 Kepahiang \\ syamsudin2018@gmail.com
}

\begin{abstract}
ABSTRAK
Tujuan Penelitian ini adalah untuk mengetahui apakah model pembelajaran kooperatif tipe Jigsaw pada materi Statistika dapat meningkatkan hasil belajar peserta didik. Penelitian ini dilaksanakan dalam 2 siklus dengan subjek penlitian adalah siswa kelas XI IPA. Pengumpulan data dilakukan melalui butir soal tes dan lembar observasi aktifitas siswa. Hasil penelitian, dari analisis data diperoleh data keaktifan siswa meningkat sebanyak $7,95 \%$ dan pada tabel rata-rata pemahaman siswa terhadap materi statistik secara klasikal menunjukan peningkatan dari 62,9\% menjadi $74,3 \%$. Simpulan, penerapan model pembelajran tipe jigsaw dapat meningkatkan hasil belajar peserta didik pada materi statistik.
\end{abstract}

Kata Kunci : Jigsaw, Hasil Belajar, Model Pembelajaran

\section{ABSTRACT}

The study aims at knowing whether or not the application of Jigsaw in the material of statistics can improve students achievement. Tujuan Penelitian ini adalah untuk. It was done in two cycles with grade XI IPA as the subject. The data collection was through objective test and observation sheets. The result: from the analysis, students activities were improved to $7,95 \%$ and in the table the students comprehension on the material was improved from $62,9 \%$ to $74,3 \%$. In summary, the application of Jigsaw can improve students learning achievement in statistics material.

Keywords: Jigsaw, Learning Achievement, Teaching Model 


\section{PENDAHULUAN}

Pendidikan merupakan sektor yang memiliki peran sangat penting dalam pembangunan, terutama dalam meningkatkan sumber daya manusia. Oleh karena itu pemerintah bersama masyarakat terus beupaya meningkatkan dan menyempurnakan penyelenggara pendidikan nasional sebagai upaya mencerdaskan kehidupan bangsa dan meningkatkan kualitas lembaga pendidikan.Untuk memantapkan sistem pendidikan yang efektif dan efesien, perlu pengembangan dan perubahan besar menghadapi pesatnya perkembangan ilmu pengetahuan dan teknologi.

Berbagai upaya sudah dilakukan pemerintah untuk memperbaiki mutu pendididkan di Indonesia, khususnya pembelajaran matematika.Upaya-upaya yang telah dilakukan antara lain melakukan perubahan kurikulum secara teratur, dengan maksud agar isi kurikulum tidak ketinggalan dengan perkembangan teknologi dan ilmu pengetahuan serta kebutuhan masyarakat yang berkembang dengan cepat.di samping itu juga, berbagai upaya dalam membekali guru agar dapat melaksanakan kegiatan PBM yang efektif dilakukan penataran-penataran guru matematika, seminar, latihan dan sebagainya. Namun semua usaha itu belum menampakkan hasil yang memuaskan, sepanjang guru masih menggunakan metode konvensional dan berorientasi pada guru bukan pada siswa, sehingga hasil akhir atau nilai yang diperoleh siswa masih belum mencapai target yang di inginkan.

Rendahnya hasil belajar siswa SMA Negeri 1 Kepahiang dalam pelajaran matematika disebabkan usaha yang dilakukan guru untuk meningkatkan hasil belajar belum berjalan seperti yang diharapkan.Pembelajaran dilaksanakan secara tradisional/ konvensional dan pola belajar siswa cenderung menerima dan menyalin teorema/definisi dan contoh-contoh yang diberikan guru.

Hal demikian merupakan faktor yang menjadikan matematika termasuk pelajaran yang tidak menarik bagi siswa SMA Negeri 1 Kepahiang khususnya kelas XI IPA 1, tampak sekali dari antusias peserta didik yang sangat rendah dalam pembelajaran matematika yang diajarkan 4 jam perminggu, dibuktikan pula dari hasil ulangan harian peserta didik yang selalu 50\% dibawah KKM.

Berdasarkan permen No. 54 tahun 2013, standar kompetensi kelompok mata pelajaran SK adapun standar Kompetensi Lulusan Satuan Pendidikan (SKL-SP) untuk SMA di antaranya adalah Kriteria mengenai kualifikasi kemampuan lulusan sikap, pengetahuan dan keterampilan. Untuk mewujudkan SKL-SP di atas maka pendidik harus berusaha maksimal, tentunya diperlukan pemikiran yang kreatif dan inovatif. Inovasi pendidikan tak hanya pada inovasi sarana dan prasarana pendidikan serta kurikulum saja melainkan saja melainkan juga proses pendidikan itu sendiri.

Inovasi dalam proses pembelajaran sangat diperlukan guna meningkatkan prestasi yang maksimal. Inovasi dalam proses pembelajaran sanga diperlukan guna meningkatkan prestasi yang maksimal. Inovasi ini dapat dilakukan dengan 
menggunakan beberapa pendekatan pembelajaran, strategi pembelajaran dan model pembelajaran. Model pembelajaran yang dilakukan oleh guru mempunyai peranan yang sangat penting dalam keberhasilan pendidikan. Penggunaan model yang tepat akan menentukan keefektifan dan keefesienan dalam proses pembelajaran dan guru harus senantiasa mampu memilih dan menerapkan model yang tepat sesuai dengan materi yang di ajarkan.

Dalam pembelajaran ada metode yang telah lama digunakan oleh para guru antara lain metode ceramah, metode Tanya jawab, dan serentetan metode tersebut bolehh dikatakan metode konvensional. Model pembelajaran konvensional yang selama ini digunakan oleh sebagian besar guru sudah tidak sesuai dengan jaman, karena pembelajaran yang dilakukan kurang memberikan kesempatan seluasnya kepada siswa untuk mengkonstruksi pengetahuan yang mereka miliki.

Ada beberapa model pembelajaran dapat digunakan untuk meningkatkan kreatifitas peserta didik dalam proses belajar antara lain model penemuan terbimbing, model pemecahan masalah, model pembelajaran portofolio dan model pemebelajaran kooperatif ada bebebrapa tipe yaitu tipe Investigation Grup ( Grup Penyelididkan ), tipe Jigsaw, tipe Stufent Teams Divisions ( STAD)

Model-model tersebut Penulis sadari belum pernah dilakukan oleh Penulis sehingga Nampak prestasi siswa dalam hasil belajar matematika belum kelihatan.Untuk itulah aktifitas belajar dirancang sedemikian sehingga memungkinkan bagi peserta didik dapat belajar lebih santai dan menyenangkan. Juga dapat menumbuhkan rasa tanggung jawab, kerja sama, persaingan sehat dan keterlibatan belajar. Melalui belajar kelompok diharapkan keaktifian peserta didik dalam pembelajaran matematika mengalami peningkatan prestasi sebab peserta didik ikut berperan aktif dan dapat memperoleh informasi tambahan dari kelompok lain.

\section{METODE PENELITIAN}

\section{Siklus 1}

Perencanaan meliputi; (a) merencanakan model yang akan diterapkan dalam proses belajar mengajar yakni model pembelajaran tipe jigsaw, (b) menyiapkan bahan pelajaran yang sesuai dengan program semester yaitu Statistika, (c) mempersiapkan rencana pelaksanaan pembelajaran, (d) mempersiapka tugas-tugas yang akan diberikan dan soal yang akan dikerjakan dalam kelompok diskusi, (e) membuat daftar nama kelompok diskusi, (f) mempersiapkan lembar obsevasi, (g) mempersiapkan lembar evaluasi. Tindakan meliputi; (a) mengkondisikan situasi kelas agar proses belajar mengajar berjalan dengan baik, (b) menyampaikan tujuan pembelajaran, (c) menginformasikan kepada peserta didik tentang model pembelajaran yang digunakan, (d) membagi peserta didik atas 7 kelompok yang heterogen, (e) memberikan tugas 
yang akan didiskusikan oleh setiap kelompok, (f) memberitahu tentang model pembelajarn Jigsaw berikut aturan main dan waktu, (g) prentase hasil kerja kelomopk diskusi, (h) membimbing peserta didik untuk mengambil kesimpulan. Pengamatan meliputi; (a) melakukan pengamatan pada waktu tindakan sedang berjalan jadi keduanya berlangsung dalam waktu yang bersamaan, (b) mencatat semua hal yang terjadi selama pelaksanaan tindakan berlangsung, (c) mengambil data berupa nilai hasil ulangan peserta didik secara individu yang merupakan hasil dari pembelajaran model tipe Jigsaw. Refleksi meliputi; tahapan refleksi dilakukan untuk mengevaluasi proses pembelajaran matematika dengan model pembelajaran kooperatif Jigsaw yang diterapkan pada siklus 1 dengan memperhatikan indicator (a) efektifitas pembelajaran, (b) perkembangan interaksi belajar mengajar, (c) peningkatan kektifan siswa, (d) peningkatan kompetensi siswa

\section{Siklus 1I}

Perencanaan meliputi. Merencanakan tindakan yang akan dilaksanakan pada siklus II sesuai dengan hasil refleksi pada siklus I dan mempersiapkan segala sesuatu yang diperlukan. Tindakan. Pelaksanaan program tindakan II seperti pelaksanaan program tindakan I namun mengacu pada identifikasi masalah yang muncul pada siklus I yang telah ditetapkan alternatif pemecahan masalahnya Pengamatan meliputi; (a) melakukan pengamatan pada waktu tindakan sedang berjalan jadi keduanya berlangsung dalam waktu yang bersamaan, (b) mencatat semua hal yang terjadi selama pelaksanaan tindakan berlangsung, (c) mengambil data berupa nilai hasil ulangan peserta didik secara individu yang merupakan hasil dari pembelajaran model tipe Jigsaw. Refkesi. Tahapan refleksi dilakukan untuk mengevaluasi proses pembelajaran matematika dengan model pembelajaran kooperatif Jigsaw yang diterapkan pada siklus 1 dengan memperhatikan Indikator (a) efektifitas pembelajaran, (b) perkembangan interaksi belajar mengajar, (c) peningkatan kektifan siswa, (d) Peningkatan kompetensi siswa

\section{HASIL PENELITIAN}

\section{Deskripsi Kondisi Awal}

Kegiatan pembelajaran matematika di kelas XI IPA 1 dilaksanakan dengan mengunakan model Pembelajaran Jigsaw, materi yang disampaikan adalah Statistika yang meliputi ukuran pemusatan data dan ukuran penyebaran data untuk data tunggal dan berkelompok. Penelitian Tindakan Kelas ini dilakukan untuk meningkatkan hasil belajar siswa. Berdasarkan nilai yang diperoleh pada beberapa kali hasil ulangan harian semester sebelumnya menunjukkan hasil belajar matematika rata- rata $50 \%$ 
dibawah nilai Kriteria Ketuntasan Minimal (KKM) yaitu 70, hal ini menyatakan bahwa hasil belajar Matematika masih rendah.

Penelitian ini dilakukan dalam dua siklus, setiap siklus terdiri dari dua pertemuan. Pertemuan pertama pada siklus I dimulai dengan membahas materi mean ,modus dan rata-rata untuk data tunggal, pertemuan kedua membahas materi mean, modus dan rata-rata untuk data berkelompok, pertemuan ketiga ulangan harian yang pertama sedangkan pada siklus II untuk pertemuan pertama membahas kuartil untuk data tunggal, pertemuan kedua membahas materi kuartil untuk data berkelompok pertemuan ketiga ulangan harian yang kedua. Kegiatan pembelajaran di kelas XI IPA 1 sebelum diadakan penelitian kondisi siswanya sebagian besar pasif, malu untuk bertanya saat mengalami kesulitan belajar serta siswa yang aktif menjawab pertanyaan hanya beberapa siswa yang pintar saja.

\section{Hasil Pengamatan}

Berdasarkan hasil ulangan harian 1 pada sikus I diperoleh data seperti terdapat pada tabel berikut:

Tabel 1

Hasil Belajar Siswa pada Siklus I

\begin{tabular}{lll}
\hline Hasil Belajar & Jumlah Siswa & Persentase \\
\hline Tuntas & 22 & $62,97 \%$ \\
\hline Tidak Tuntas & 13 & $37,1 \%$ \\
\hline Jumlah & 35 & $100 \%$ \\
\hline
\end{tabular}

Tabel 1 di atas merupakan hasil belajar pada siklus 1 dengan banyak siswa yang memperoleh nilai $\geq$ KKM sebanyak 22 siswa $(62,9 \%)$, dan yang belum tuntas 13 orang $(37,1 \%)$.

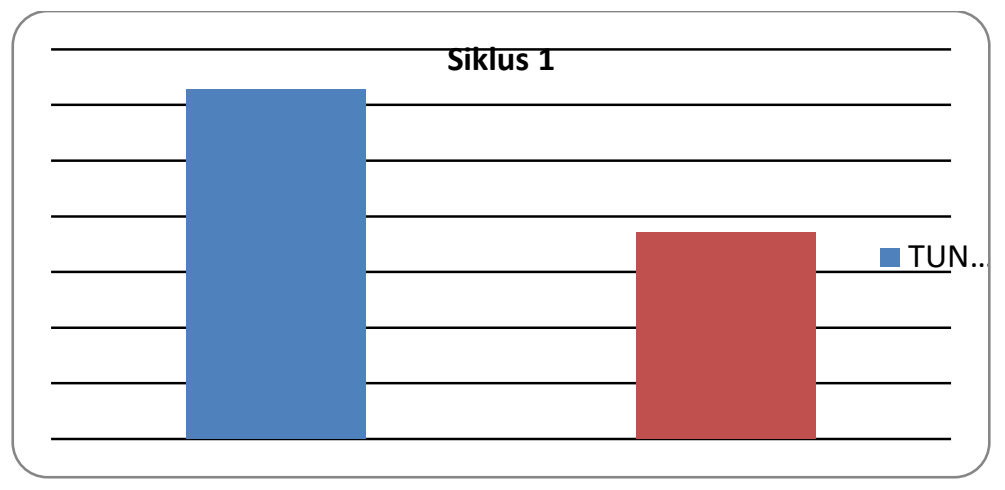

Grafik 1. Hasil Belajar Siswa pada Siklus I 


\section{Pengamatan terhadap Aktifitas Siswa}

Berdasarkan hasil pengamatan, peneliti memperoleh data aktifitas siswa pada siklus 1 sebagai berikut:

Tabel 2

Data Aktivitas Siswa pada Siklus I

\begin{tabular}{llll}
\hline Aktivitas & Pertemuan 1(\%) & Pertemuan 2 $(\%)$ & Rata-Rata \\
& & & \\
\hline Sikap aktif & 74,3 & 74,4 & 74,35 \\
\hline Bekerja sama & 72,4 & 73,2 & 72,8 \\
\hline Toleransi & 67,6 & 68 & 67,8 \\
\hline
\end{tabular}

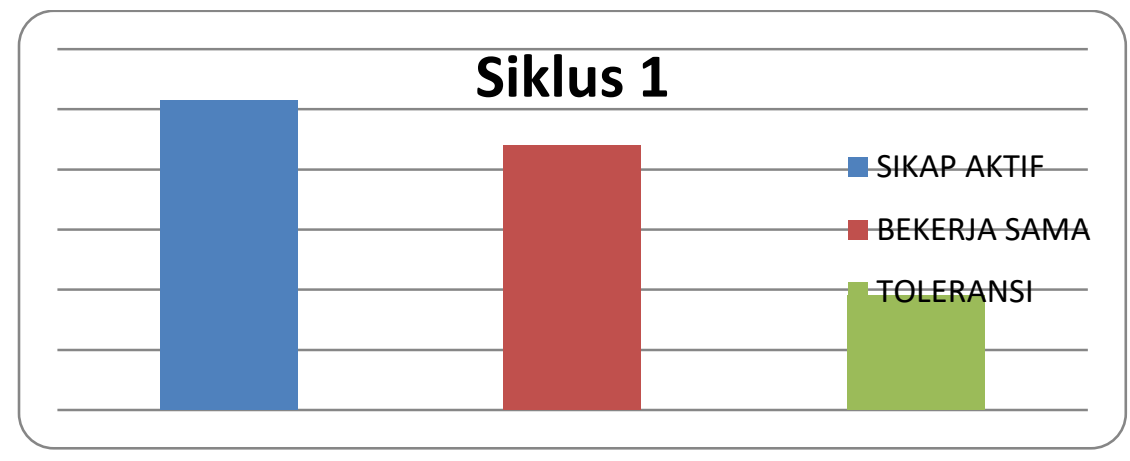

Grafik 2. Akifitas Belajar Siswa pada Siklus I

\section{Refleksi}

Berdasarkan data hasil belajar siswa, aktifitas siswa dan peneliti pada proses pembelajaran siklus I, maka hasilnya dapat direfleksikan bahwa hasil belajar siswa sudah mulai ada perubahan yaitu $62,97 \%$, peningkatan siswa yang tuntas KKM tidak lagi dibawah 50\%, walaupun belum mencapai hasil ketuntasan secara klasikal yaitu jumlah rata-rata siswa yang tuntas . 70\%. Bila dilihat dari kriteria penilaian aktivitas siswa lebih dari $50 \%$ siswa aktif dalam pembelajaran. Semua kekurangan dan kelemahan yang terdapat pada siklus I dijadikan acuan untuk perbaikan pada pelaksanaan silus II. 


\section{Deskripsi Hasil Siklus II Perencanaan Tindakan}

Sebelum melaksanakan kegiatan pembelajaran, peneliti melakukan perencanakan dengan langkah-langkah mempersiapkan rencana pelaksanaan pembelajaran (RPP) dengan menggunakan model peembelajaran Jigsaw. Mempersiapkan bahan ajar Matematika dengan materi Statistika menngenai Ukuran penyebaran datai. Mempersiapkan naskah soal tes ulangan harian untuk pembelajaran siklus II (Naskah soal ulangan harian terlampir). Mempersiapkan lembar observasi kegiatan aktifitas siswa dan guru (Lembar observasi terlampir)

\section{Pelaksanaan Tindakan}

Pelaksanaan tindakan pada siklus II dimulai tanggal 3 s.d 4 Februari 2016. Pertemuan pertama membahas materi kuartil untuk data tunggal, pertemuan kedua membahas materi kuartil untuk data berkelompok dan pada pertemuan ketiga pelaksanaan Ulangan Harian 2. Adapun langkah-langkah pelaksanaan tindakan yang dilakukankan pada siklus II ini masih mengikuti langkah-langkah yang terdapat dalam Rencana Pelaksanaan Pembelajaran (RPP) sebelumnya.

\section{Hasil Pengamatan}

Berdasarkan hasil ulangan harian 2 pada sikus II diperoleh data berikut:

Tabel 3

Hasil Belajar Siswa pada Siklus II

\begin{tabular}{ccc}
\hline Hasil Belajar & Jumlah Siswa & Persentase \\
\hline Tuntas & 26 & $74,3 \%$ \\
\hline Tidak Tuntas & 9 & $25,7 \%$ \\
\hline Jumlah & 35 & $100 \%$
\end{tabular}

Dari tabel di atas bila dibuat dalam bentuk grafik akan nampak seperti gambar di bawah ini

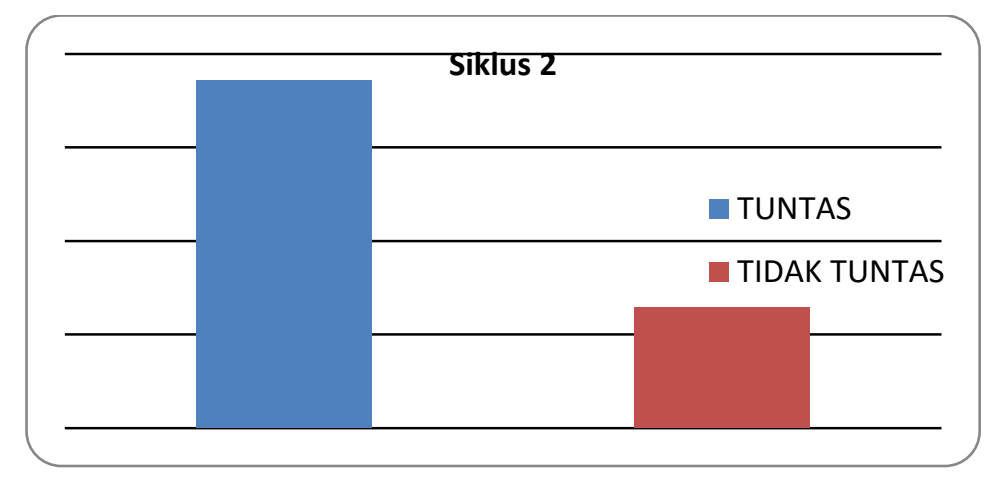

Grafik 3. Hasil Belajar Siswa pada Siklus II 


\section{Pengamatan terhadap Aktifitas Siswa}

Berdasarkan hasil pengamatan, peneliti memperoleh data aktivitas siswa pada siklus II sebagai berikut:

Tabel 4

Data Aktivitas Siswa pada Siklus II

\begin{tabular}{llll}
\hline Aktivitas & Pertemuan 1 & Pertemuan 2 & Rata-Rata \\
& $(\%)$ & $(\%)$ & \\
\hline Sikap aktif & 83,8 & 87,6 & 85,7 \\
\hline Bekerja sma & 76 & 77 & 76,5 \\
\hline Toleransi & 79 & 81 & 80 \\
\hline
\end{tabular}

Dari tabel di atas bila dibuat dalam bentuk grafik akan nampak seperti gambar di bawah ini:

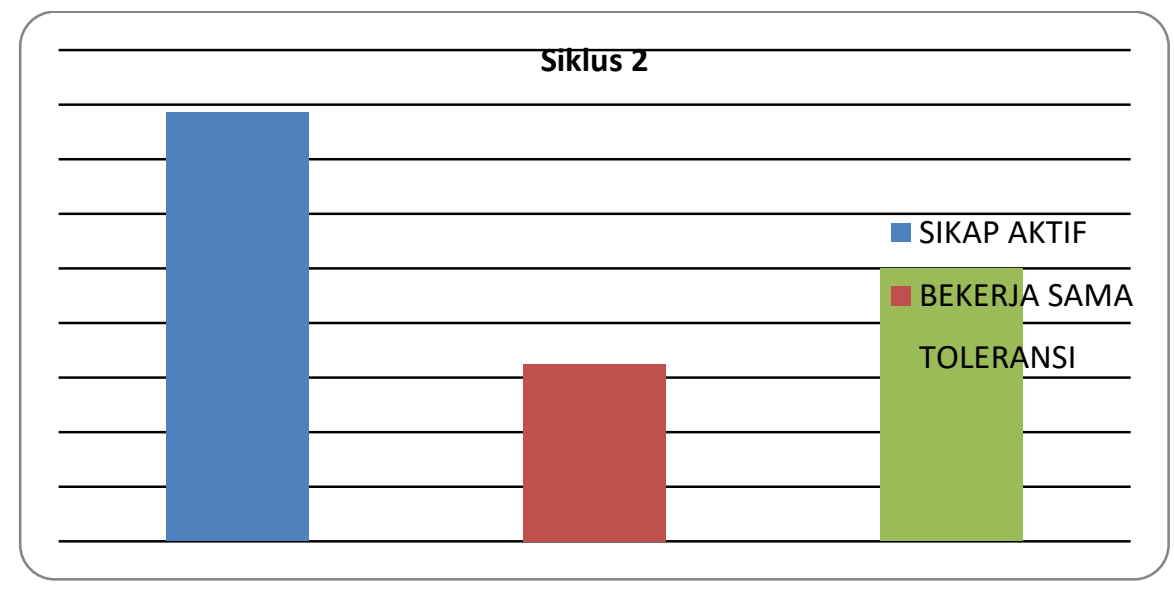

Grafik 4. Akifitas Belajar Siswa pada Siklus II

\section{Refleksi}

Berdasarkan data hasil belajar siswa, aktifitas siswa dan peneliti pada proses pembelajaran siklus II, maka hasilnya dapat direfleksikan bahwa hasil belajar siswa sudah ada perubahan yaitu 74,3\%, siswa dinyatakan sudah tuntas KKM. Keaktifan siswa dalam kegiatan pembelajaran sudah merata pada tiap-tiap kelompok, baik keaktifan siswa dalam kerjasama, keberanian siswa dalam bertanya dan menjawab 
pertanyaan. Pengelolaan waktu dalam diskusi dan presentasi sudah terkontrol sesuai alokasi waktu yang disediakan dalam RPP. Penyempurnaan langkah-langkah kegiatan pembelajaran pada siklus II berdampak positif bagi peningkatan hasil belajar siswa, aktifitas siswa dan peneliti, oleh karena itu peneliti membatasi hanya pada siklus II.

\section{PEMBAHASAN}

Hasil belajar siswa pada siklus I diperoleh hasil sebagai berikut yang tuntas sebanyak 25 orang $(67,57 \%)$ dan yang tidak tuntas sebanyak 12 orang (32,43\%) sedangkan pada siklus II yang tuntas sebanyak 26 orang $(74,3 \%)$ dan yang tidak tuntas sebanyak 9 orang (25,7\%). Perbandingan hasil belajar siswa pada siklus I dan siklus II dapat dilihat pada tabel berikut:

Tabel 5

Perbandingan Hasil Belajar Siklus I dan II

\begin{tabular}{lllll}
\hline \multirow{2}{*}{ Hasil Belajar } & \multicolumn{2}{c}{ Siklus I } & \multicolumn{2}{c}{ Siklus II } \\
\cline { 2 - 5 } & Banyak Siswa & Persentase & Banyak Siswa & Persentase \\
\hline Tuntas & 22 & 62.9 & 26 & 74,3 \\
\hline Tidak Tuntas & 13 & 27,1 & 9 & 25.7 \\
\hline
\end{tabular}

Berdasarkan tabel 5 di atas ternyata hasil belajar siswa ada peningkatan dari siklus I ke siklus II sebanyak 11,4\%. Peningkatan ini dipengaruhi oleh perbaikanperbaikan dari kekurangan atau kelemahan yang dialami pada siklus I. Perbandingan hasil belajar pada siklus I dan siklus II bila ditampilkan dalam bentuk grafik akan nampak seperti berikut:

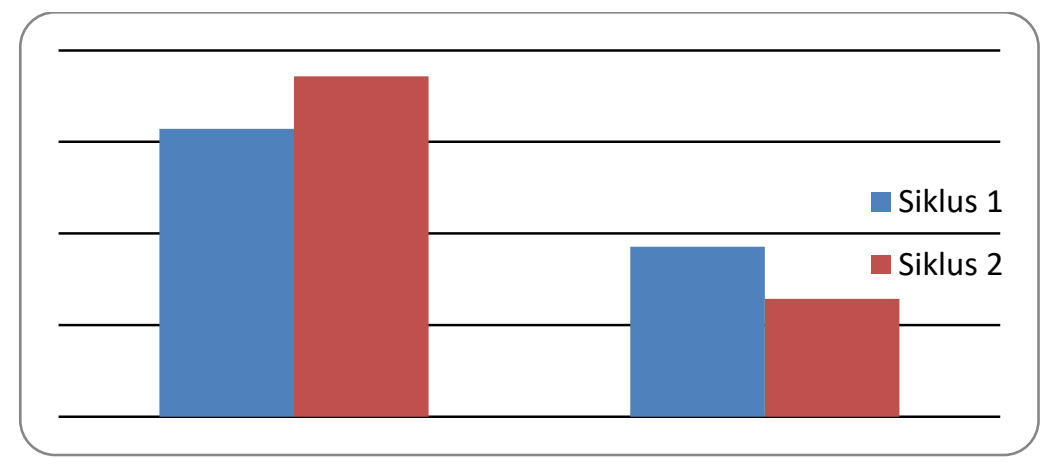

Tabel 5. Grafik Perbandingan Hasil Belajar Siklus I dan II 
Dari data diatas menunjukkan bahwa hasil belajar pada siklus II mengalami peningkatan dibandingkan pada siklus I, berarti penggunaan model pembelajaran Jigsaw dapat meningkatkan hasil belajar, Aktifitas belajar siswa yang diperoleh pada siklus I dan siklus II dapat dilihat pada tabel berikut:

Tabel 6

Perbandingan Aktifitas Belajar Siswa pada Siklus I dan II

\begin{tabular}{|l|l|l|}
\hline Aktivitas Belajar Siswa & $\begin{array}{l}\text { Rata-Rata Siklus I } \\
(\boldsymbol{\%})\end{array}$ & $\begin{array}{l}\text { Rata-Rata Siklus II } \\
(\boldsymbol{\%})\end{array}$ \\
\hline Sikap aktif & 74,35 & 85,7 \\
\hline Bekerja sama & 72,8 & 76,5 \\
\hline Toleransi & 67,8 & 80 \\
\hline
\end{tabular}

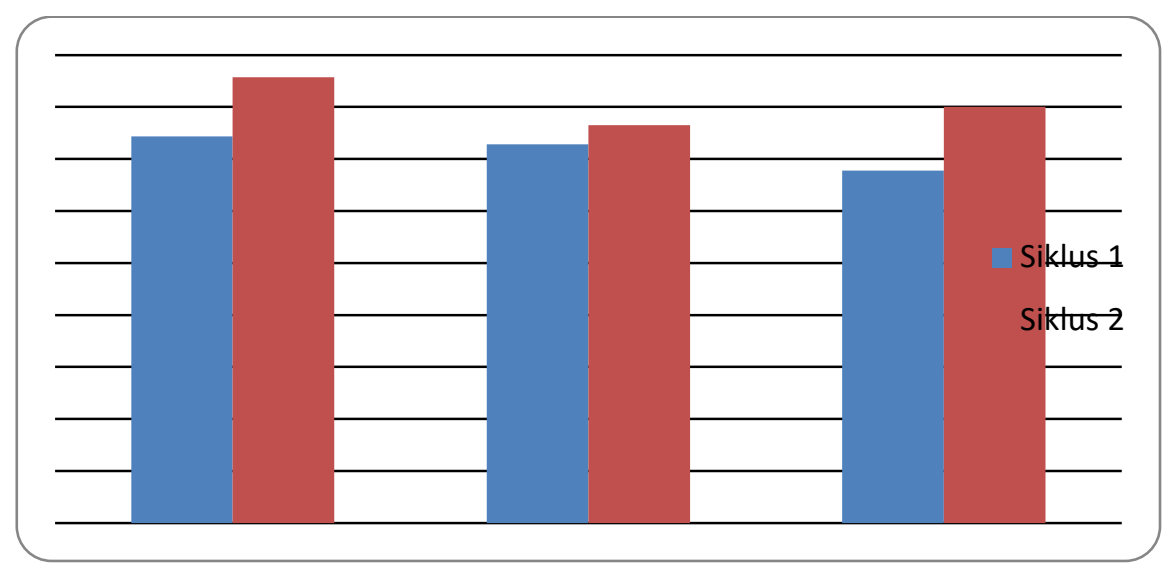

Tabel 6. Grafik Perbandingan Hasil Belajar Siklus I dan II

\section{SIMPULAN}

Dari hasil penelitian yang dilakukan penelti selama dua siklus menyimpulkan bahwa penggunaan model pembelajaran Jigsaw sangat efektif untuk meningkatkan hasil belajar siswa, hal ini di tandai dengan adanya peningkatan ketuntasan hasil belajar siswa dari siswa yang tidak tuntas sebanyak 13 orang $(37,1 \%)$ pada silkus I menurun menjadi 9 orang $(25,7 \%)$ pada siklus II demikian juga dengan aktifitas siswa semakin menunjukan pola belajar yang kondusif dan meningkatnya keaktifan siswa baik dalam aktifitas kerjasama, menumbuhkan sikap percaya diri untuk bertanya saat mengalami kesulitan dalam belajar dan keberanian menjawab bila ada pertanyaan yang disampaikan sehingga sikap malu-malu secara bertahap terkikis dengan menumbuhkan penghargaan pada setiap aktifitas yang dilakukannya juga bagi 
peneliti semakin memberikan wawasan bahwa selama ini beranggapan cara ceramah, pembelajaran berpusat pada guru akan memberikan cara cepat agar dipahami oleh siswa ternyata pemikiran itu kurang tepat karena dengan pemilihan model pembelajaran yang tepat contohnya model pembelajaran Jigsaw yang dilakukan oleh peneliti ternyata membawa dampak yang besar bagi peningkatan hasil belajar, keaktifan siswa dan ketercapaian peneliti dalam menyampaikan materi pembelajaran.

\section{DAFTAR PUSTAKA}

Arikunto, S. (2010). Prosedur Penelitian. Jakarta: Gramedia Hamdani. (2010). Strategi Belajar Mengajar. Bandung: Pustaka Setia.

Rusman. (2011). Model-model Pembelajaran, Mengembangkan Profesionalisme Guru. Jakarta: Raja Grafindo Persada.

Slameto. (2008). Belajar dan Faktor-faktor yang Mempengaruhinya. Jakarta: Rineka Cipta 